\title{
US-China Relations: Nationalism, the Trade War, and COVID-19
}

\author{
Brandon M. Boylan ${ }^{1}$ (D) Jerry McBeath ${ }^{2} \cdot$ Bo Wang $^{3}$
}

Received: 9 July 2020 / Accepted: 25 September 2020 / Published online: 4 October 2020

(c) Fudan University 2020

\begin{abstract}
The trade war between the USA and China has shocked many across the world. A disruption to the interdependence of the two largest economies seemed unfathomable. However, in an effort to thwart China's economic practices and boost the US economy, President Trump's administration levied tariffs on Chinese imports shortly after taking office, moving US foreign economic policy from liberalism, practiced for decades, to protectionism. China has retaliated, and the trade war continues today. With conceptual insights from the nationalism literature, we explore the nationalist roots of the trade war from both the US and Chinese perspectives. In the USA, the Trump administration's plan to achieve energy autonomy, decrease reliance on foreign resources, and reinvigorate the manufacturing sector has led to protectionist policies, the othering of China, and hence the trade war. Although reluctant to enter the conflict, China has rebuffed the USA, resisting and counterattacking US actions, owing to a long-felt sense of persecution in the global space and an eagerness to participate fully, and lead in some issue areas, in international affairs. The conflict continues into the COVID-19 era, marked by US scapegoating of China and hits to economic performance. Until both sides are convinced they have achieved their goals, or the USA undergoes an administration change, the conflict will likely continue.
\end{abstract}

Keywords US-China relations · Nationalism · International trade $\cdot$ Natural resources $\cdot$ Energy $\cdot$ Political economy $\cdot$ COVID-19

\section{Introduction}

Linking the two largest economies, the US-China trade relationship is the world's most important. However, in recent years, nationalism in each country, the trade war, and COVID-19 have strained this relationship. Guided by the literature on

Brandon M. Boylan

bmboylan@alaska.edu

Extended author information available on the last page of the article 
nationalism, we explore how rising nationalist frustrations in both the USA and China have contributed to the trade war, a conflict exacerbated in the COVID-19 era. While they have common elements, the sources of nationalism in the two countries are different. In the USA, a growing segment of the domestic public, believing it lacked political representation and protection of its values, responded to an "America First" agenda, culminating in the election of Donald Trump. In return, President Trump has continued to oppose China for domestic political support, particularly from the manufacturing and agricultural sectors and from an ethnically and religiously homogeneous base. In China, political leaders resented the lack of global political status commensurate with rapid economic growth and rising military might. They demanded more respect for their sphere of influence, and they mobilized against US threats to Chinese sovereignty. Indeed, China has aspirations to global leadership status on par with the USA and Russia.

In this article, we first provide the main features of the US-China trade war. We then highlight insights from the nationalism literature to frame the ways in which nationalist grievances in the USA and China have contributed to the ongoing trade dispute. From the US side, we examine the push for energy independence, the revival of manufacturing, and internal and external xenophobia-factors that have led to the scapegoating of China and motivated the conflict. From the China side, we assess historical victimization, economic reforms and internationalism, and leadership in the international community. Feeling a sense of historical repression, and with a goal of being a full participant in global affairs, China has asserted economic and political power in the trade conflict. Throughout, we discuss how the COVID-19 pandemic has influenced the trade war.

\section{Background: The US-China Trade War (2016-present)}

During his presidential election campaign, Donald Trump routinely condemned China for what he and others believed were unfair trade practices and decried its trade surplus with the USA (BBC News 2016). Promoting an "America First" foreign policy agenda marked by US nationalism, protectionism, and unilateralism, and appealing simultaneously to large corporations (through tax cuts) and the US manufacturing and agricultural sectors (through shoring up jobs), he vowed to take a hard line on China in response to its reported currency devaluation, export subsidies, and theft of US intellectual property (Long 2016; Daniels 2016).

As president, Trump oversaw the establishment of economic policies that launched a trade war, placing tariffs and nontariff restrictions on Chinese imports. In early 2018, his administration imposed tariffs on imported solar panels and washing machines (Lynch 2018) and later on steel and aluminum (Donnan 2018). Although the tariffs applied to imports from many countries, Chinese goods were seemingly the primary target. In retaliation, China imposed tariffs on an array of products from the USA. From July to December 2018, the tariff war escalated in a tit-for-tat fashion. After fragile progress of negotiations in early 2019, the Trump administration raised tariffs from 10 to $25 \%$ on $\$ 200$ billion worth of Chinese goods in summer 2019 (Bryan 2019). China retaliated with its own tariffs. In August 2019, 
China suspended the purchase of new US agricultural products, and the U.S. Treasury Department declared China a "currency manipulator" (U.S. Department of the Treasury 2019). The two countries made progress in repairing trade relations in fall 2019 and agreed to a trade deal in January 2020. However, despite the deal, in which China promised to import more US agricultural goods, it has not met its purchasing targets, especially in the wake of COVID-19 (Bermingham 2020).

China's decreased importation of agricultural products from the USA has harmed US farmers. These products include soybeans, grain sorghum, pork, cotton, and cattle hides. Although China purposefully targeted the US agricultural base in the hope that farmers would pressure the Trump administration (Li et al. 2018), farmers continued to support the president. Based on surveys of corn and soybean farmers in 2018, Zhang, Rodriguez, and Qu argue that three factors account for their support (Zhang et al. 2019): First, the Trump administration has given billions in assistance to offset profit losses. Second, farmers believe that decline in profits in the short term will lead to better gains in the long term. Third, China has been inconsistent over time in its purchases of agricultural goods, according to farmers. Thus, despite Chinese efforts and some economic setbacks, farmers could continue to support the president.

The Trump administration has also attempted to thwart Chinese theft of intellectual property and espionage. In May 2019, it banned US companies from working with Huawei, a large Chinese multinational telecommunications and electronics company, over concerns it was stealing intellectual property and spying on companies and the government (Paletta et al. 2019). A month later, it targeted five supercomputing companies-Chengdu Haiguang Integrated Circuit, Chengdu Haiguang Microelectronics Technology, Higon, Sugon, and the Wuxi Jiangnan Institute of Computing Technology_over fears they were using their technology for military purposes (Leonard and Donnan 2019). In June 2020, President Trump proposed visa restrictions on Chinese students and scholars associated with China's "militarycivil fusion strategy" in the belief that the Chinese government used them to acquire intellectual property illegally from the USA (Redden 2020). In late July 2020, the Federal Bureau of Investigation (FBI) arrested Chinese students who had not disclosed they had connections with the People's Liberation Army (PLA) when applying for admissions and student employment positions at various US universities. Chen, Chen, and Dondeti contend that "the trade war is not, in fact, about trade but about technological dominance, and that both sides might fall into a 'Thucydides's Trap,' the pattern of large-scale conflict when a rising power challenges a dominant one" (Chen et al. 2020).

Amid the COVID-19 outbreak, President Trump referred to the disaster as the "Chinese virus" (Rogers et al. 2020) and later, at a rally in Tulsa, Oklahoma, as "Kung Flu." He said that the US government is determining if the virus originated from the Wuhan Institute of Virology. He has also accused the World Health Organization (WHO) of acting like the "public relations agency for China" and has withdrawn US funding from the institution (Al Jazeera 2020).

Trump's former National Security Advisor John Bolton accused him of asking President Xi Jinping for domestic support in his bid for reelection (Bolton 2020). In one example, Bolton argued that Trump pressured China to purchase large amounts 
of soybeans to boost farmers' support as the presidential election neared. Indeed, the president has had a difficult balance to achieve: remaining politically and rhetorically tough on China for failing to keep many of its trade promises and for cracking down on Hong Kong, while encouraging a market rebound before the election, itself partly contingent on the progress of US-China trade relations. Meanwhile, his credibility and trustworthiness seem to fluctuate in accordance with this inconsistent behavior.

From the Chinese perspective, the trade war has come as a surprise. In earlier administrations, and especially since China's entry into the WTO in 2000, trade relations had been amicable and permissive. Chinese were thus shocked at President Trump's unconventional approach to negotiations by threatening to increase tariffs on Chinese goods and to do so swiftly. Chinese leaders interpreted this as bullying or baling in Mandarin ("ba" meaning a "tyrant," and "ling" meaning "insulting"). "Face" or mianzi is an essential virtue in traditional Chinese culture, and Trump's coercive and bullying approach awakened memories of the "100 years of humiliation," when foreign powers transgressed Chinese sovereignty. For many, the chief culprit became the USA. However, the Chinese state media employed a moderate approach in covering the trade conflict, criticizing the Trump administration for its protectionist policies instead of blaming the USA as a whole for economic aggression (Zeng and Sparks 2020).

Chinese commentators on the growing trade hostilities took different stances. $\mathrm{Hu}$ Xijin and Jin Canrong, both with large bases of support, voiced incendiary economic nationalist memes. Moderate opinion leaders, such as Yao Yang (a professor at Beijing University), called for a rational and cooperative approach in the management of US-China trade disputes (Yao 2019). Spokespersons for the Chinese Ministry of Foreign Affairs occasionally used tit-for-tat discourse as the conflict unfolded, which foreign audiences probably thought was undiplomatic. Ironically, economic nationalists welcomed this type of rhetoric that targeted a domestic audience. However, it was subject to misperception by foreign actors (Wang and McNeil 2019). The Chinese Ministry of Commerce is less visible to the Chinese public than the Ministry of Foreign Affairs is, and it is largely free from the pressure of Chinese nationalism. During the trade negotiations, it played a constructive role as the economic and commercial expertise while its officers built confidence across the negotiating table.

The outbreak of the COVID-19 pandemic, first in China and then in Europe, the USA, and elsewhere, made bilateral trade negotiations more complicated. Controversies outside the trade conflict-for example tensions in the South China Sea, the Chinese national government's promulgation of national security articles in Hong Kong, US-China disputes concerning the WHO, and the like-added fuel to the flames of nationalism. Upon the rapid deterioration of political and security relations between the two countries, first Foreign Minister and Chinese Community Party (CCP) Political Bureau member Wang Yi, and then Yang Jiechi (also a CCP Political Bureau member), delivered speeches dismissing talk of US-China disengagement. Yang also visited the USA and met with Secretary of State Mike Pompeo to ease tensions. Speeches of Chinese leaders expressed a willingness to cooperate and compromise with their US counterparts, and they also served to bridle disorderly domestic nationalist impulses. 


\section{Nationalism: A Review of the Literature}

In this section, we review concepts and literature related to nationalism to develop a foundation to analyze the drivers of the US-China trade war. These concepts include nationalism, state nationalism, economic nationalism, and American exceptionalism. Elites have long employed nationalist ideas to differentiate from others, and at times scapegoated and blamed these differentiated others, to achieve their strategic objectives.

Nationalism is a devotion to the nation and its people, identity, and culture. It stems from a national consciousness and prioritization that is in opposition to or comes at the expense of other nations. Often, social movements spring from nationalist convictions and aim to protect and promote the nation. Gellner (1983) argues that the principal goal of nationalism is to achieve the congruence of the national and political units. Infrequently do the boundaries of nations and states completely align, however, and movements to build nation-states often fail. Civic nationalism is a movement to advance the political community, while ethnic nationalism aims to advance the political, economic, and cultural interests of the ethnic group. Smith argues that nationalism is "an ideological movement to attain and maintain autonomy, unity, and identity on behalf of a population, some of whose members believe it to constitute an actual or potential "nation" (Smith 2009, 61).

State nationalism is a form of civic nationalism that attempts to transform the sovereign state to a nation, what can be called the "state-nation." State nationalists contribute to this agenda by othering and marginalizing both internal and external actors. To build the state-nation, leaders and their followers scapegoat ethnic and racial minorities, immigrants, and political and cultural challengers within the state, while at times paradoxically embracing some of these ethnic and political "others" if they support the nation building project. State nationalists blame global forces, international institutions, and other countries and peoples for their challenges, revisioning them as threats to the state's advancement of their interests and to state expansionism. Leaders and followers in the state-nation project have a complex and mutually reinforcing alliance. Leaders reward their constituents with rhetorical and material benefits in exchange for their support to exact a domestic and foreign policy agenda to move the state to a state-nation. This alliance is often tenuous: Leaders' failure to deliver these rewards could weaken constituent support. State nationalism ranges from benign patriotism on the one end of the spectrum to violent fascism on the other.

One form of state nationalism is state economic nationalism (or mercantilism). Economic nationalism is an ideology that prioritizes the state's economy over all others. Economies elevate state security and military power according to the ideology. Economic wealth is seen in realist and zero-sum ways. A leading international relations realist, and scholar of economic nationalism, Gilpin (1987, 31) writes, "Its central idea is that economic activities are and should be subordinate to the goal of state-building and the interests of the state." He further argues, it "recognizes the anarchic nature of international affairs, the primacy of the state 
and its interests in international affairs, and the importance of power in interstate relations" (Gilpin 2001, 14). Contrasting economic liberalism, it opposes globalization and free trade and what is deemed as their destructive forces. Instead, economic nationalists aim to safeguard and control their own economies through protectionist measures like tariffs, quotas, and excessive regulations. Economic nationalism aims for economy diversification, while economic liberalism aims for specialization. Often, industrialization processes and the manufacturing and agricultural sectors are prioritized in the economic nationalist perspective. Economic nationalists routinely scapegoat others for economic losses. Such others include economic liberals and other countries. (A racialized version also blames immigrants and ethnic minorities.) China's version of economic nationalism has been state corporatism, in which the government intervenes heavily in the market and owns or partially owns many corporations.

Although nationalist movements are pervasive around the world, nationalism in the USA holds a distinctive place in world history. A young state but old democracy, the USA is often characterized by its "exceptional" status - a label first applied by de Tocqueville (1838). As old as the country itself, American exceptionalism is rooted in the American Revolution and U.S. Constitution. According to Lipset (1996), Americans are committed to a common set of values: individualism, antistatism, populism, and egalitarianism. As the "first new nation" (Lipset 1963), other states are not born out of the same suite of ideals. Based on a conviction that the USA is not only exceptional but superior, the USA believes it has a special mission to transform the world, which has justified international interventionism and democracy promotion since World War I. Inherent in American exceptionalism is a recognition of how the USA differs from other countries-both enemies and allies.

As we show in the next sections, the Trump administration has both galvanized and capitalized on domestic economic frustrations to perpetuate a state nationalist project to secure support for its domestic and foreign policy goals. In the international sphere, this project has targeted primarily China. Meanwhile, China's recent economic and political rise is also driven by nationalism and an antagonism toward the USA. Although nationalism in each country contributes to the trade war, the roots and character of these nationalisms differ.

\section{Expressions of Nationalism in the USA and China}

\subsection{Nationalism in the USA and the Othering of China}

Nationalism in the USA has contributed to the othering of China and the ongoing trade war. In this section, we consider three expressions of US nationalism: energy independence, revival of manufacturing, and internal and external xenophobia and then assess how each contributes to the trade conflict. The Trump administration's push to become more energy independent, decrease the country's reliance on foreign resources, and protect manufacturing jobs has led to the resurgence of economic protectionism. Veiled in xenophobic rhetoric, China has been made a target in this context in an attempt to increase domestic support. 


\subsubsection{The Push for Energy Independence}

The Trump administration has striven for energy independence. It has aggressively pursued fossil fuels and minerals development in the country, with critical financial and political support early in the administration (2017-2018) and rollback of environmental laws and rules considered obstacles to energy independence and economic development before and during the COVID-19 pandemic. Shortly after his election to the presidency in 2016, Trump promised a new era of "energy dominance," a term he coined, perhaps to imply that there would be no obstacles to increasing production of conventional and tight oil and gas, making coal "king" again for electricity generation, and expanding nuclear energy and hydropower (Council on Foreign Relations 2017). This was a much more aggressive agenda than that of previous Republican presidents, and it responded to the interests of large oil companies, allied interests (e.g., oil field service firms), and constituent groups such as older Caucasian voters, the lower middle class, and less educated workers.

Having promised during his presidential campaign that he would end the "war on American energy," Trump, three years into his presidency, claimed that the USA had attained energy dominance. As the economic recession and COVID-19 pandemic spread in the USA, the Trump administration went to great lengths to further the objectives of the fossil fuel industry. In forming a task force called the "Great American Economic Revival" of industry groups to "reopen" the economy, he appointed nine executives from oil and gas corporations, two from the utility sector, one from oil mining, but no one from renewable industries. Then, in early 2020 when oil and gas prices decreased, Trump played a broker role seeking a reduction in global oil production from Saudi Arabia and Russia. The president tweeted, "We will never let the great Oil \& Gas Industry down ... I have instructed the Secretary of Energy and Secretary of the Treasury to formulate a plan ... so that these very important companies and jobs will be secured long into the future" (Dillon 2020). He sought to reduce the global oil glut and ease pressure on US oil and gas, reserve prices for which were briefly negative.

When administration plans to purchase millions of barrels of oil for the Strategic Petroleum Reserve (SPR) conflicted with Congress, the U.S. Department of Energy leased space providing aid to the industry (Lee and Clark 2020). The U.S. Federal Reserve Board of Governors increased liquidity in the economy, and then the president and Congress offered the largest stimulus program since the Great Depression (by mid-2020, amounting to nearly $\$ 5$ trillion). Hundreds of billions in loans-much of which did not need to be repaid-went to businesses harmed by the pandemic, including energy companies (Cahlink and Koss 2020).

Republicans, and industries such as tobacco, oil and gas, coal, and chemicals, have long advocated for revision of federal agency, especially EPA, rulemaking. The Trump administration placed regulatory reform high on its agenda and planned an unprecedented rollback of environmental regulations, but the reform process was interrupted by the transition in power as Democrats gained control of the House after the 2018 midterm elections and then the 2019 impeachment proceedings. Regulatory reform gained urgency for the upper echelons of the administration in 2019, especially as energy prices fell and the stock market failed. 
The Trump administration's targets of regulatory reform have long been icons of the US environmental movement: the Clean Air Act, the National Environmental Policy Act (NEPA), the Clean Water Act, as well as Waters of the US (WOTUS) regulations. Critics viewed these regulations as impeding energy and other apparently hazardous proposed developments. Too, regulatory reforms limited the application of the Endangered Species Act (ESA) protections of migratory routes and curbed the length of public comment periods for responding to proposed Environmental Impact Statements (EIS) reviews. Altogether these rollbacks challenged the environmental law and regulatory system established in a generation, although environmental groups challenged all reforms in court (see, for example, Farah and Hijazi 2020).

The Trump administration also sought to expand access to federal lands for oil and gas drilling, coal mining, and mining of strategic minerals such as rare earth elements (see Hao and Liu 2011). Most remaining US public lands are in the West, and since the Sagebrush Rebellion of 1982, elected federal and state officials in western states have resisted "federal overreach." Thus, the administration's efforts garnered praise, while environmentalists and a few other interests (e.g., cattle ranchers, fisheries) were in opposition. Moreover, lands once reserved from development of rare, precious, and threatened species, such as the western sage grouse, were opened as well. By mid-2020, the USA produced 95 percent of the fossil fuels it consumed.

Energy independence is a subset of economic nationalism. The Trump administration aims to decrease its reliance on other states for fossil fuels (e.g., oil, gas, and coal) and use US resources to provide power to factories, businesses, and residences. Energy independence increases national power in competition with global rivals (e.g., Russia) that are self-sufficient in fossil fuels. It increases national economic development and wealth, as few expensive resources need to be imported. And it increases diplomatic flexibility, as preferred outcomes (e.g., support for Israel) are not constrained by resource dependence. Fossil fuel dominance also protects and rewards large oil and gas corporations that have bankrolled Republican leaders including President Trump, and it ensures continued employment for hundreds of thousands of oil/gas/coal field workers and sustenance of communities in which they live. This expression of nationalism is linked directly to trade protectionism and thus the US-China trade war.

\subsubsection{The Revival of Manufacturing}

The decline of US manufacturing was an issue in the 1980s, and the circumstances regarding manufacturing enterprises have worsened since then (Pierce and Schott 2016). In the 2016 election, candidate Donald Trump called for a renaissance of manufacturing. As the economic downturn set in, and then the COVID-19 pandemic erupted, the focus became primarily the automobile industry and the global supply chain that undergirded it.

The US automobile business was once dominated by the "Big 3"-General Motors (GM), Chrysler, and Ford. However, the Detroit auto industry's continued production of high fuel consumption vehicles, when oil shocks pushed gas prices skyward, created openings for inexpensive, fuel-efficient foreign automobiles. To 
cultivate political support, increasingly foreign manufacturers opened plants in the USA. Notwithstanding attempts by some manufacturers to limit foreign sourcing of auto parts, the supply chain for vehicles became more global than national. The Detroit auto industry lost considerable political support when GM and Chrysler, having declared bankruptcy, gained bailouts of $\$ 64$ billion from the federal government in 2009, as corporate executives flew by Lear jets to Washington, DC for hearings (Lassa 2011).

Given their global linkages, US multinationals were at odds with President Trump's rhetoric. For example, in a cost-cutting action GM announced it would close five factories and lay off 14,000 workers in North America. In response, the president tweeted that he was considering ending electric vehicle (EV) subsidies: "General Motors made a big China bet... when they built plants there ... don't think this bet is going to pay off. I am here to protect America's Workers!" (Joselow 2018).

As President Trump began his reelection campaign in 2019, he claimed, "Many, many plants are now under construction in Michigan and Ohio, Pennsylvania, North Carolina, South Carolina, Florida. They hadn't built one in decades and now they're all over the place." Although little new plant construction occurred under the Trump administration (Robertson 2019), the industry had become compliant with the president. As auto sales fell, and the COVID-19 crisis erupted in early 2020, Trump administration agencies allowed exemptions to warehouse and factory safety restrictions so that workers would not lose their jobs. When in March 2020 US car sales seemed likely to drop more than $40 \%$, and US factories closed, the industry received loan guarantees, tax deductions for employees' paid leave, and deferred corporate tax payments. The president also used the emergency provisions of the Defense Production Act to configure factories of GM, Ford, and Tesla to produce ventilators and other medical supplies (Joselow 2020).

Through action on new fuel efficiency standards, the Trump administration made its strongest efforts to revive the auto industry. The trend since 1974 had been to reduce the amount of gasoline or diesel fuel consumed by cars and light trucks through raising standards of miles-per-gallon. Shortly after taking office, the Trump administration proposed a rollback of Obama administration targets which would have the effect of increasing US greenhouse gas emissions, while reducing the prices of cars and trucks. The auto industry was divided about the proposal. The catalyst was the Koch brothers and their conservative network, but most environmental nongovernmental organizations (NGOs) were opposed. A New York Times investigation contended that the motivation behind the campaign to lower fuel efficiency standards was the surplus of fossil fuels in the USA and the need to increase demand for their products (and fossil fuel dominance) (Tabuchi 2018). This change, along with historically low gas prices, gave US automakers strong incentives to produce more big "dirty" cars (Ferris 2020).

Manufacturing nationalism is another form of economic nationalism. Although it increases consumer costs, as US labor and most material costs are higher than those in Mexico and other developing nations, reversing the hollowing out of US corporations avoids the flight of US jobs to Mexico (through the North American Free Trade Act) and emerging economies (through the World Trade Organization). It 
increases national wealth and power by spurring innovation and technology, which lead to productivity growth. Increasing exports and reducing imports improves economic health by reducing reliance on other states. Too, reduction in balance of payments deficits makes the USA more competitive vis-à-vis its global rivals, especially China. New manufacturing enterprises add hundreds of thousands of jobs to the economies of depressed regions and states and electoral success to national leaders. This form of economic nationalism inspires protectionism and has contributed to the US-China trade war.

\subsubsection{Internal and External Xenophobia}

Xenophobia in the USA can be internal or external. The internal, or inward, dimension refers to actions and events within the country and involves the scapegoating of persons or groups along racial, ethnic, religious, or gender lines. The external, or outward, dimension refers to the racialized and hostile treatment of other countries. For example, in the George W. Bush administration, an "axis of evil" (North Korea, Iran, and Iraq) preoccupied US policymakers. In the Trump administration, the fixation has been on Mexico and China. Political elites use both forms of xenophobia in an attempt to garner domestic support.

During the 2016 presidential campaign, Trump lambasted previous administrations for failing to enforce border security and stop drug smugglers and other criminal elements from entry into the USA. The most potent message of his campaign was to "build a wall," and this appealed strongly to Caucasians (and even some Latinos) in his base. During the first two years of his administration, construction of new sections to the already existing wall was a regular story on the public agenda. Most dramatic was conflict between the executive and the House of Representatives when the latter body, under Democratic control after the 2018 midterm election, refused to appropriate funds to pay for wall construction. The ensuing government shutdown was the longest in US history. The administration did stop the flow of immigrants and began the return of some asylum seekers, but US law made instant resolution impossible.

Republican leaders focused on the "flood" of illegal immigrants, most from Central America transiting through Mexico to cross the US border. The numbers had escalated since the previous immigration reform legislation, totaling at least 11 million. In addition to their lack of legal status, illegal immigrants, according to the critics, used US public services (schools, hospitals, and reduced transportation and housing fares) at taxpayers' considerable expense and took jobs from US citizens. Supporters of legalizing immigrants' status offered evidence that immigrants on balance contributed toward the services they received and in most cases worked in jobs (e.g., farm labor, domestic cleaning, and health care) that most Americans did not desire.

Economic and political conflicts with China changed the dynamics of xenophobia in the USA. As mentioned, conflicts over trade rules and policies grew during the second and third year of the Trump presidency, and relations worsened greatly when the COVID-19 pandemic reached the US homeland. President Trump and several conservative pundits accused China of genetic manipulations in Wuhan laboratories, 
causing outbreak of the virus and then failing to disclose it, a pattern repeating the Chinese regime's actions in the 2002-2003 SARS epidemic. Then, US leaders accused China of infiltrating US laboratories, research institutes, and universities; stealing intellectual property; and hacking US computer systems. Several Chinese students who were apprehended had worked for the China's People's Liberation Army (PLA).

By mid-year 2020, US-China relations had become the worst since 1972. In addition to trade sanctions, risky military encounters (e.g., Chinese ships in the US continental shelf), the cessation of nearly all flights into the USA from China (and most of those from the USA to China), and the closure of the Houston consulate exacerbated relations. The US labeled Huawei Technologies Co. and its telecom companion ZTE as a national security threat. Secretary of State Mike Pompeo said that the relationship between the two nations should be based on the principle of "distrust and verify" and went on to say that the diplomatic opening of China by President Nixon in 1972 had undermined US interests (Wang and Myers 2020).

Both political and economic dimensions of nationalism stimulated xenophobic responses within the USA and in its international behavior. The political malaise was the expression of endless wars fought by the USA without clear victory or just compensation for its contributions. Economic discontent was the result of several decades of globalization that left large numbers of citizens behind (e.g., less educated, laid-off manufacturing workers). Political leaders and particularly Donald Trump exploited this dissatisfaction and its victims and found targets to blame: foreigners (e.g., Central Americans, Mexicans, Chinese, Africans) and Democrats (who supported "illegal" immigrants and were the elites of the "deep state" who grew rich from globalization). Scapegoating of these groups relieved emotional stress of those who believed they had been forgotten. Once mobilized, leaders then directed the anger of the "forgotten" to others, and the states appearing to represent them, such as China. This strategy has become a dominant feature of President Trump's reelection campaign.

\subsection{Nationalism in China and the Othering of the USA}

Although China's history as a civilization extends many thousands of years into the past, its modern identity as a nation dates to the nineteenth century, and it is expressed in four forms: economic, ethnic, cultural and political. Nationalist sentiments in China, as in the USA, have contributed to the trade war. From a longfelt perspective of being persecuted, and with a desire to participate fully in global affairs and exert leadership over some issue-areas, China has rebuffed US demands and contributed to the trade war.

\subsubsection{Historical Victimization}

An ancient source of Chinese nationalism is its long history as a civilization. China prides itself on the longevity of the Chinese language and culture and the ancient belief that China was the central power of the world. Chinese leaders are keen to 
create state nationalism and unity in light of the multiethnic composition of the population. Chinese nationality formally includes all of the state's official 56 ethnic groups. Although more than $90 \%$ of the people are Han Chinese, leaders state that cultural inclusiveness is an important value (Gao and Zhu 2010), despite the reality. China celebrates an elaborate tribute system, brought up to the present in the Belt and Road Initiative. It also has a global diaspora, which connects mainland China to hundreds of thousands of Chinese communities throughout the world.

Most Western researchers, including ethnic Chinese researchers in the West, emphasize China's memory of humiliation from foreign invasion, particularly the "100 years of humiliation" from the Opium War to the end of World War II and past grievances at the hands of foreign enemies. From this follows the memory of identity as a victimized people, who should "never forget national humiliation" (Wang 2012; Zhao 2014). Western scholars' research in other contexts has suggested that nationalism is one of several factors driving public support for aggressive external policies. Some see a rise in aggressive nationalist rhetoric from both official and popular sources (see, among others, Whiting 1995). In the 1990s, the media provided greater opportunity and incentives for grassroots nationalist expressions (He 2007). They featured angry and sometimes violent protests following international incidents involving the USA and Japan (Gries 2001). This has led several Western observers to characterize Chinese nationalism as irredentist, insecure, and virulently anti-foreign (Whiting 1995), and this played a role in the increase of regional and bilateral tensions (Cotillon 2017; Yahuda 2013). On the other hand, some Chinese opinion leaders believe China has been subject to provocation analogous to that of Germany and Japan before World War II. Nationalist commentators, such as $\mathrm{Hu}$ Xijin (chief editor of Global Times), Jin Canrong (professor at Renmin Universitiy), $\mathrm{Hu}$ An'gang (professor at Tsinghua University), and Kong Lingdong (professor at Beijing University), appear to subscribe to radical nationalist beliefs and have large Internet followings. In either case, a nationalism centered on a long-felt sense of persecution has contributed to the ongoing trade war. China's history of being othered has created a "we" and "they" mentality and an insecurity that four decades of economic growth cannot easily remedy.

\subsubsection{Economic Reforms and Internationalism}

Modern Chinese economic reform emerged at the fall of the Qing Dynasty in 1911-1912 and the rise of the Republic of China, notwithstanding political turmoil until the establishment of the People's Republic of China (PRC) in 1949. Private entrepreneurship, which had long been suppressed under imperial rules, thrived, as evidenced in the slogan, "entrepreneurship saves China" (shiye jiuguo). After three decades of Marxist and Maoist rule, China's reforms and Open Door policies were adopted upon Deng Xiaoping's return to power in 1978. More recently, China has strategized to invest ambitiously in locations all around the world, from Africa to the Arctic, and trade with a host of partners, all supported by the Belt and Road Initiative, a strategy to develop roads, railways, and ports in several countries around the globe. 
Economic reforms established state capitalism as a system to create wealth and power in China. State-owned enterprises remained pillars of the economy, in sectors of national security importance such as transportation, energy, natural resource extraction and production, electricity, and several types of manufacturing. China's doors were opened to multinational corporations and importation of their technology and capital. China's integration into the global economy brought great pride in the Chinese nation as it became the world's premier production center. Chinese competitiveness was essential for reduction of poverty and the rise of a middle class, but this came at the cost of national independence-as noted in xenophobic responses associated with both cultural and ethnic nationalism and directed at groups like the Uyghers, Tibetans, and Taiwanese.

China has been able to provide elementary school education to nearly all youth. Middle school education is not yet universal, and access to high school and college is limited to those passing entrance examinations. Still, young people today are much more likely to be knowledgeable about the global community than they were fifty years ago. The increase in educational opportunity facilitates independent and critical thought about the linkage of China's national interest and economic interdependence (Qin and Zhu 2005). Further, scholars generally agree that economic reforms increasing competitiveness and promoting global integration have been beneficial to China's national interest (Chen 2000; Brien and He 2002). Therefore, as the Trump administration sought to sever economic and cultural ties with China, the majority of Chinese, including elites, objected. They wanted to prevent a trend leading to disengagement from global affairs. When Chinese considered the degree to which China had advanced as a consequence of ties with the outside world and particularly the USA, they harnessed nationalist instincts in the developing trade war.

\subsubsection{Leadership in the International Community}

The Chinese Communist Party was founded on Marxism, and during the first three decades of the PRC the regime followed the Soviet model of a state-owned and managed economy. During that period, ideological disputes within the fabric of Marxism and Maoism prompted the Great Leap Forward to surpass the USA and UK, followed by the Cultural Revolution which attempted to purge capitalist elements from society. Less than two decades later, leaders staged a "patriotic education campaign," designed to shore up support for the CCP in the wake of the student movement of 1989 and the setback to Marxism as represented in the fall of the Berlin Wall and ultimate dissolution of the Soviet Union in 1991.

Western scholars' research on Chinese nationalism focuses on public attitudes and foreign policy making (Weiss 2014; Sinkkonen 2013). For Chinese leaders, the politics of nationalism are more complicated and have both domestic and foreign targets. President Xi Jinping envisions China and the global community as sharing a common destiny and expects China to play a positive and active leadership role in global governance. In Xi's vision of the Chinese dream, China will exercise responsibility in producing more public goods, including harmonious interactions between humans and nature (Bhattacharya 2019). Thus, Xi is under pressure to end the trade war and reassert China's growing leadership role in international relations. 
This vision of China's role in global governance, along with China's visible benefits from participation in the global economic system, most notably with the USA, are key factors balancing against the bitter feelings Chinese harbor toward the Trump administration for disrespectful treatment during the course of trade negotiations. China and the USA have different political and ideological belief systems. China is an outsider to the global security network, which features a US-led alliance network. These differences will be difficult to eliminate in the short term, and for this reason trade relations increasingly appear risky. When these factors become dormant, trade issues will be easier to resolve. Of course, increasing global economic benefits would ease trade hostilities, but the slowdown in global growth due to the COVID-19 pandemic limits the ability of both China and the USA to soften in their trade positions. A number of uncertainties remain for both countries regarding the role nationalism plays in trade relationships. In the USA, domestic politics are polarized, and there are problems in economic recovery. In China, there are concerns in the process of domestic political development as to whether the Open Door and economic reform policies should continue. Too, there is the question of China's identity as a responsible global actor. Thus, China counteracts US aggression in the trade war, not only to protect its economic interests but also to assert power to international audiences.

\section{Conclusion}

Although the Trump administration initiated the trade war, China has retaliated with tit-for-tat measures and exerted a great deal of power to protect its economic and political interests and its burgeoning leadership role in global affairs. Both sides' participation in the conflict rests on several nationalist factors. In the USA, President Trump has pushed to wean the country off foreign sources of oil and other natural resources and has promised to bring manufacturing jobs back to the Rust Belt and other areas. Both of these agenda items have led to economic nationalist and protectionist steps and to the weakening of the US-China trade relationship. In this context, Trump and other high-level administrators have used xenophobic rhetoric in an attempt to blame China for US economic ills. The rhetoric ramped up at the onset of the COVID-19 pandemic (and in the year of a presidential election campaign). For the Trump administration, the pandemic was an opportunity to further blame China for domestic economic problems long in the making. Initially surprised at the high tariffs imposed on its goods, China has stood up to US pressure, in part owing to its identity of being historically marginalized and its desire to continue to grow economically and politically on the world stage.

What have been the effects of the US-China trade conflict? It has led to higher consumer prices, lower corporate profits, unstable markets, and slower economic growth (Norland 2020; Ungarino 2019; Lawder 2020). One analysis shows how President Trump's tweets related to the trade conflict have adversely affected the stock market (Burggraf et al. 2019). Account deficits and manufacturing decline in the USA are the result of low savings, high labor costs, and rising service sectors rather than imports from China (Sheng et al. 2019). Of greater alarm, the trade war 
has exacerbated account deficits and eroded the USA's comparative advantage in the technological sector and human capital by pressuring China to invest in high technology industries (Sheng et al. 2019). Moreover, deficit reductions have not promoted economic growth (Moosa 2020), and the trade deficit reduction with China will likely lead to deficits with other countries (Lai 2019). It appears that the USA will not reduce its trade deficit with China, and even if it could do so, the USA will not achieve strong economic progress but instead develop deficits with other countries.

The Trump administration, as long as it is in power, will likely not let up in its pressure toward China. Its othering of China continues to be relevant as long as the USA continues to maintain unsatisfactory wages and societal interruptions owing to the pandemic. Although the USA has legitimate reasons for pressuring China, the country is also a convenient target for domestic grievances. Although China would prefer to return to the status quo, it will resist and counterattack US actions to both prevent economic decline and showcase power to domestic and foreign audiences.

Funding We did not receive funding for this research.

Code Availability We do not use a software program for this paper and do not have separate coded data.

\section{Compliance with Ethical Standards}

Conflict of interest We have no conflicts of interest or competing interests in this project.

Availability of Data and Materials Our data are open source and cited.

\section{References}

Al Jazeera. Trump Claims Coronavirus Came from Wuhan Lab, May 4, 2020.

BBC News. Trump Accuses China of 'Raping' US with Unfair Trade Policy, May 2, 2016.

Bermingham, Finbarr. China Falling Further behind US Trade Deal Energy Targets, Even as Crude Oil Imports Soar to Record Volumes, South China Morning Post, June 9, 2020.

Bhattacharya, Abanti. 2019. Chinese Nationalism Under Xi Jinping Revisited. India Quarterly: A Journal of International Affairs 75(2): 245-252.

Bolton, John. John Bolton: The Scandal of Trump's China Policy. The New York Times, June 17, 2020.

Brien, K.O., and Xiaoqin He. 2002. Globalism and China's Economic Development. Journal of Jiangxi University of Finance and Economics 1: 3-6.

Bryan, Bob. Trump Just Ramped Up Tariffs on \$200 Billion Worth of Chinese Goods. Here Are All the Products That Will Get Hit. Business Insider, May 10, 2019.

Burggraf, Tobias, Ralf Fendel, and Toan Luu Duc Huyn. 2019. Political News and Stock Prices. Applied Economics Letters 27(18): 1485-1488.

Cahlink, George, and Geof Koss. House Sends \$2.2 T Stimulus Bill to Trump, E\&E News, March 27, 2020.

Chen, Ping. 2000. WTO and Economic Nationalism: China's Car Industry in the 21st Century. Modernization of Management 3: 36-40.

Chen, Anthony W., Jim Chen, and V. Reddy Dondeti. 2020. The US-China Trade War: Dominance of Trade or Technology? Applied Economics Letters 27(11): 904-909.

Cotillon, Hannah. 2017. Territorial Disputes and Nationalism: A Comparative Case Study of China and Vietnam. Journal of Current Southeast Asian Affairs 36(1): 51-88.

Council on Foreign Relations (CFR). 2017. Timeline: Oil Dependence and U.S. Foreign Policy. 
Daniels, Jeff. US Files Trade Complaint over China's 'Excessive' Ag Subsidies, CNBC, September 13, 2016. Dillon, Jeremy. Trump Wants Lifeline for Struggling Industry, E\&E News, April 21, 2020.

Donnan, Shawn. Donald Trump to Slap 25\% Tariff on Steel Imports. Financial Times, March 1, 2018.

Farah, Niina, and Jennifer Hijazi. 'Blow Up in Their Face.' Trump NEPA Rule Faces Legal Assault. E\&E News, July 16, 2020.

Ferris, David. Clean Cars Rollback Adds to EVs’ Pain. E\&E News, April 1, 2020.

Gao, Yongjiu, and Jun Zhu. 2010. From National Identity to National Identity in a Multi-National Country. Ethno-National Studies 2: 26-35.

Gellner, Ernest. 1983. Nations and Nationalism. Oxford: Basil Blackwell.

Gilpin, Robert. 1987. The Political Economy of International Relations. Princeton: Princeton University Press.

Gilpin, Robert. 2001. Global Political Economy: Understanding the International Economic Order. Princeton: Princeton University Press.

Gries, Peter Hays. 2001. Tears of Rage: Chinese Nationalist Reactions to the Belgrade Embassy Bombing. The China Journal 46: 25-43.

Hao, Yufan, and Weihua Liu. Rare Earth Minerals and Commodity Resource Nationalism, National Bureau of Asian Research (NBR) Special Report \#31, September 2011.

He, Yuan. 2007. History, Chinese Nationalism, and the Emerging Sino-Japanese Conflict. Journal of Contemporary China 16(5): 1-24.

Joselow, Maxine. GM Doesn't Care What Trump Tweets. E\&E News, November 30, 2018.

Joselow, Maxine. Automakers Send Coronavirus Requests to Congress. E\&E News, March 24, 2020.

Lai, Edwin L.-C. 2019. The US-China Trade War, the American Public Opinions, and Its Effects on China. Economic and Political Studies 7(2): 169-184.

Lassa, Todd. U.S. Market Share for the Top Five Automakers. Motortrend, December 17, 2011.

Lawder, David. Drag from Trump's Trade Wars Continues to Ripple through U.S. Economy. Reuters, January $14,2020$.

Lee, Mike, and Lesley Clark. Trump Says Demand Is Back. But Companies May Not Survive, E\&E News, May 11, 2020.

Leonard, Jenny, and Shawn Donnan. Trump Blacklists More China Tech Companies Days before Xi Summit. Bloomberg News, June 21, 2019.

Li, Minghao, Wendong Zhang, and Chad Hart. 2018. Lessons from Previous U.S.-China Trade Disputes. Agricultural Policy Review 2018 Issue 2, Article 1: 1-3.

Lipset, Seymour Martin. 1963. The First New Nation: The United States in Historical and Comparative Perspective. New York: Basic Books.

Lipset, Seymour Martin. 1996. American Exceptionalism: A Double-edged Sword. New York: W.W. Norton \& Co.

Long, Heather. How China Doesn't Play Fair on Trade. CNN Business, July 12, 2016.

Lynch, David J. Trump Imposes Tariffs on Solar Panels and Washing Machines in First Major Trade Action of 2018. The Washington Post, January 22, 2018.

Moosa, Imad A. 2020. The Thucydides Trap as an Alternative Explanation for the US-China Trade War. Global Journal of Emerging Market Economies.

Norland, Erik. Trade War Costs to Consumers, Companies and Nations. Financial Times, June 20, 2020.

Paletta, Damian, Ellen Nakashima, and David J. Lynch. Trump Administration Cracks Down on Giant Chinese Tech Firm, Escalating Clash with Beijing: The President Also Signed an Executive Order to Protect U.S. Networks from Foreign Espionage, a Move That Appears to Target China. The Washington Post, May 15, 2019.

Pierce, Justin, and Peter Schott. 2016. The Surprisingly Swift Decline of US Manufacturing Employment. American Economic Review 106(7): 1632-1662.

Qin, Yaqing, and Liqun Zhu. 2005. Neo-internationalism and China's Diplomacy. Foreign Affairs Review 5: 21-24.

Redden, Elizabeth. Trump Proclamation Bars Entry of Certain Chinese Students. Inside Higher Ed, June 21, 2020.

Robertson, Lori. Trump's Repeated Falsehood on Auto Plants. FactCheck.Org, June 21, 2019.

Rogers, Katie, Lara Jakes, and Ann Swanson. Trump Defends Using 'Chinese Virus' Label, Ignoring Growing Criticism. The New York Times, March 18, 2020.

Sheng, Liugang, Hongyan Zhao, and Jing Zhao. 2019. Why Will Trump Lose the Trade War? China Economic Journal 12(2): 137-159.

Sinkkonen, Elina. 2013. Nationalism, Patriotism, and Foreign Policy Attitudes among Chinese University Students. The China Quarterly 216: 1045-1063. 
Smith, Anthony D. 2009. Ethno-Symbolism and Nationalism. New York: Routledge.

Tabuchi, Hiroko. The Oil Industry's Covert Campaign to Rewrite American Car Emissions Rules. The New York Times, December 13, 2018.

Tocqueville, Alexis de, 1805-1859. 1838. Democracy in America. New York: G. Dearborn \& Co..

Ungarino, Rebecca. As Trump's Trade War Escalates to 'New Heights. Business Insider, August 24, 2019.

U.S. Department of the Treasury. Treasury Designates China as a Currency Manipulator. Press Release, August 5, 2019.

Wang, Zheng. 2012. Never Forget National Humiliation: Historical Memory in Chinese Politics and Foreign Relations. New York: Columbia University Press.

Wang, Edward, and Steven Myers. Officials Push U.S.-China Relations Toward Point of No Return. The New York Times, July 25, 2020.

Wang, Yanan, and Sam McNeil. China Voices Strength, Pushes Nationalism around Trade War. AP News, May 15, 2019.

Weiss, Jessica Chen. 2014. Powerful Patriots: Nationalist Protest in China's Foreign Relations. Oxford: Oxford University Press.

Whiting, Allen S. 1995. Chinese Nationalism and Foreign Policy after Deng. The China Quarterly 149: 295-316.

Yahuda, Michael. 2013. China's New Assertiveness in the South China Sea. Journal of Contemporary China 22(8): 446-459.

Yao, Yang. 2019. Gu Chui Zhong Mei Tuo Gou Shi Weixian De. ("It Is Dangerous to Advocate ChinaUS Disengagement.”) Caixin Net. Retrieved August 15, 2020 from http://opinion.caixin.com/2019-0807/101448255.html.

Zeng, Wena, and Colin Sparks. 2020. Popular Nationalism: Global Times and the US-China Trade War. International Communication Gazette 82(1): 26-41.

Zhang, Wendong, Lulu Rodriguez, and Shuyang Qu. 2019. 3 Reasons Midwest Farmers Hurt by the U.S.China Trade War Still Support Trump. The Conversation. Retrieved August 20, 2020 from https://theco nversation.com/3-reasons-midwest-farmers-hurt-by-the-u-s-china-trade-war-still-support-trump-12630 3.

Zhao, Suisheng. 2014. A Nation-State by Construction: Dynamics of Modern Chinese Nationalism. Palo Alto: Stanford University Press.

Dr. Brandon M. Boylan is Associate Professor of Political Science and Director of Arctic \& Northern Studies at the University of Alaska Fairbanks (UAF). His research focuses on international relations, international security, political violence, terrorism, ethnic conflict, and separatist movements. His work has been published in International Studies Perspectives, Journal of Common Market Studies, Conflict Management and Peace Science, Nations and Nationalism, and Studies in Conflict and Terrorism, among others. His collaborative projects have been funded by the National Science Foundation, US Department of Commerce, and Norwegian Centre for International Cooperation in Education. He teaches a range of undergraduate and graduate courses in international relations, comparative politics, and research methods. He is faculty advisor for Model United Nations and Model Arctic Council at UAF. He holds a Ph.D. in International Affairs from the University of Pittsburgh.

Dr. Jerry McBeath is Professor Emeritus of Political Science at the University of Alaska Fairbanks (UAF). His publications include approximately sixty journal articles and book chapters and sixteen books, the most recent of which are Big Oil in the United States (McBeath, 2016) and Environmental Education in China (McBeath and McBeath, with Tian Qing and Huang Yu, 2014). He received his Ph.D. in Political Science from the University of California, Berkeley.

Dr. Bo Wang is Associate Professor of International Relations and Vice Dean of the School of International Relations at the University of Business and Economics in Beijing (UIBE). His research and teaching focus on international relations, international political economy, American politics, and Chinese political economy and foreign policy. He has published dozens of peer reviewed journal articles in both Chinese and English. He has also led several research programs granted by APEC, China's National Social Sciences Foundation, and other state and provincial foundations. He received his Ph.D. in International Relations from the China Foreign Affairs University. 


\section{Affiliations}

\section{Brandon M. Boylan ${ }^{1}$ (D) Jerry McBeath ${ }^{2} \cdot$ Bo Wang $^{3}$}

Jerry McBeath

gamcbeath@alaska.edu

Bo Wang

bowang@uibe.edu.cn

1 University of Alaska Fairbanks (UAF), 603 C/D Gruening Building, 1747 South Chandalar Drive, Fairbanks, AK 99775, USA

2 Emeritus of Political Science, University of Alaska Fairbanks (UAF), 1777 Red Fox Drive, Fairbanks, AK 99709, USA

3 School of International Relations, China University of International Business and Economics (UIBE), Mail Box 100, No. 10 Huixin East Street, Changyang District, Beijing 100029, People's Republic of China 